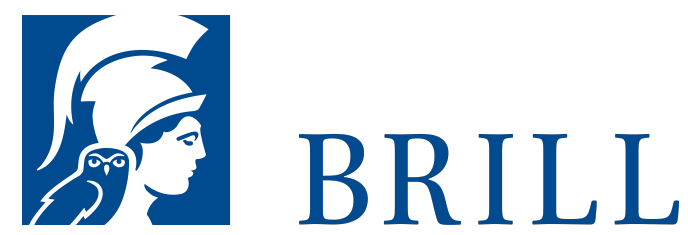

\title{
Enhancing Human Performance via Simulation-based Training and Aiding
}

\author{
Polities, Politics, Performances
}

Author: Douglas M. Towne

This volume presents an object-oriented approach for developing interactive graphical device models and for delivering instruction and performance aiding with such models. The volume attempts to illustrate, via a series of examples, why and how the particular design given satisfies relatively intensive and diverse instructional and performanceaiding demands with surprising ease.

The early chapters focus on the fundamental design concepts upon which all applications stand, including a consistent design of the basic elements - objects - from which all models are produced; a clear separation between the model of the target domain and the instructional processes; and, wherever possible, automatic generation of user interactions, based on the structure and content of the model.

Each of the later chapters focus on one particular application area, including explication of complex system functions, diagnostic instruction and guidance, procedural guidance, scenario-based instruction, and simulation-based technical documentation.

The volume is intended to serve instructional designers, curriculum developers, and software implementers, an ambitious scope that is hopefully achieved via the early presentation of critical "nuts-and-bolts", followed by discussions of specific training and aiding environments that can be more selectively considered. The more complex examples presented in...

See More

Readership

Educational Researchers and their students 
For more information see brill.com

Order information: Order online at brill.com +44330 333 0049 | customerservices@brill.com Submission information: brill.com/authors

Titles published by Brill | Fink, Brill | mentis or Brill | Schöningh: +49(o)715413279216| brill@brocom.de 